\title{
Biocompatibility assessment of resin-based cements on vascularized dentin/pulp tissue-engineered analogues
}

\author{
Christina Hadjichristou ${ }^{a}$, Eleni Papachristou ${ }^{a}$, Emmanouil Vereroudakis ${ }^{b, c}$, \\ Maria Chatzinikolaidou ${ }^{b, c}$, Imad About ${ }^{d}$, Petros Koidis ${ }^{a}$, \\ Athina Bakopoulou, ${ }^{a, *}$ \\ a Department of Prosthodontics, School of Dentistry, Faculty of Health Sciences, Aristotle University of Thessaloniki \\ (AUTh), Thessaloniki, GR-54124, Greece \\ b Department of Materials Science and Technology, University of Crete, Heraklion, Greece \\ c Institute of Electronic Structure and Laser, Foundation for Research and Technology Hellas (FORTH), Heraklion, \\ Greece \\ d Aix Marseille University, Centre National de la Recherche Scientifique, Institute of Movement Sciences, Marseille, \\ France
}

\begin{abstract}
A B S T R A C T
Objectives. A three-dimensional (3D) dentin/pulp tissue analogue, resembling the human natural tissue has been engineered in an in vitro setup, aiming to assess the cytocompatibility of resin-based dental restorative cements.

Methods. Stem Cells from Apical Papilla (SCAP) and Human Umbilical Vein Endothelial Cells (HUVEC) were embedded in Collagen-I/Fibrin hydrogels at 1:3 ratio within 24-well plates. Hanging culture inserts were placed over the hydrogels, housing an odontoblast-like cell layer and a human treated-dentin barrier. Shear modulus of the hydrogels at 3.5 and $5 \mathrm{mg} / \mathrm{ml}$ was evaluated by dynamic mechanical analysis. Eluates of two resin-based cements, a dual-cure- (Breeze ${ }^{\mathrm{TM}}$, Pentron: Cement-1/C1), and a self-adhesive cement (SpeedCEMplus ${ }^{\mathrm{TM}}$, Ivoclar-Vivadent: Cement-2/C2) were applied into the dentin/pulp tissue analogue after prestimulation with LPS. Cytocompatibility was assessed by MTT assay, live/dead staining and real-time PCR analysis.

Results. Both hydrogel concentrations showed similar shear moduli to the natural pulp until day (D) 7, while the $5 \mathrm{mg} / \mathrm{ml}$-hydrogel substantially increased stiffness by D14. Both cements caused no significant toxicity to the dentin/pulp tissue analogue. C1 induced stimulation ( $p$ $<0.01$ ) of cell viability (158 $\pm 3 \%, 72 \mathrm{~h}$ ), while pre-stimulation with LPS attenuated this effect. C2 ( \pm LPS) caused minor reduction of viability $(15-20 \%, 24 \mathrm{~h}$ ) that recovered at $72 \mathrm{~h}$ for the LPS+ group. Both cements caused upregulation of VEGF, ANGP-1, and downregulation of the respective receptors VEGFR-2 and Tie-1.
\end{abstract}




\section{Introduction}

Cytocompatibility assessment of dental materials before market release is a prerequisite to maintain regulatory standards and achieve safe clinical use. Among the existing options, resin cements are the material of choice when dealing with all-ceramic restorations or lab-processed resin restorations with high aesthetic needs or for patients with metal allergies. Self-adhesive systems are continuously gaining popularity, as bonding is simplified by a single step procedure, containing all the necessary ingredients in one bottle [1]. Although promising, resin cements are not devoid of drawbacks, as they contain mono-, di- and $\phi$ r multi-methacrylate monomers, such as BisGMA, urethane oligomers of BisGMA, UDMA, HEMA, GDMA, TEGDMA, TMPTMA, just to mention a few [2]. The incomplete polymerization reaction of these monomers into a crosslinked polymer matrix leads to the release of unpolymerised unbound free monomers, such as HEMA and TEGDMA, which are able to elicit cytotoxicity directly on pulp and gingival cells [4], while it may also be involved in the allergic potential of the material [2,5]. In particular TEGDMA has been found to be more cytotoxic than other resin monomers leading to acute cytotoxicity [6], while it has also been found easily soluble in saliva and being cytotoxic [7]. The mechanisms through which these materials may exert their cytotoxic effects are numerous, including oxidative stress [8], cell cycle arrest [9], inhibition of odontogenic differentiation of pulp cells $[10,11]$ or even cell apoptosis [12]. Research has shown that an inflammatory effect, combined with disorganization of the odontoblastic layer is evident a week after the application of resin cements, and this effect may persist even for two months later in vivo [13]. Likewise, it has been shown in a $2 D$ in vitro experiment, that the cytotoxic effect is exerted as soon as the material comes in contact with the cells and gradually weakens off by the seventh day [14]. This implies that there is a discrepancy between the in vitro and in vivo results. Some events may even be missed due to the scheduled time-points of observation. In the in vivo situation it is impossible to monitor tissue reactions in real-time, which is something that may be compensated by in vitro experiments. It is also less costly to apply multiple time-points of observation in an in vitro setup compared to an in vivo arrangement. This creates the necessity of a system that resembles the 3D arrangement of the in vivo setting, but with the ability of real-time monitoring or multiple observation time-points provided by an in vitro set up.

A few experiments have been conducted to evaluate the cytotoxicity of resinous cements, mostly focusing on the evaluation of a widely-since several years-used commercially available product of the self-adhesive resin cement, RelyX (3M, USA). Most studies utilized 2D in vitro experimental settings [15-18] or in vivo settings on teeth that were predetermined to

be extracted [13]. Somewhere between the two settings (2D in vitro and in vivo), other examples of more sophisticated in vitro models can be found in the literature, such as the dentin barrier test (perfusion chamber), which was initially trialed with cells seeded in a 2D monolayer on dentin disks $[19,20]$ or more recently within 3D surrogates [21-23], following the ISO 7405:2018 specifications [24]. An even more sophisticated example of a dentin/pulp in vitro representation has been developed with the "tooth-on-a-chip" model [25] where the cytotoxicity exerted by the monomer HEMA and phosphoric acid ( $\mathrm{PA}$ ) in terms of cell morphology and metabolic activity was evaluated. All of the above approaches are aiming to incorporate the protective effect of residual dentin towards the pulp during evaluation of the response to external stimuli. In the case of in vitro trials, the $2 \mathrm{D}$ environment may not recapitulate the dimensionality of the natural tissues, which are de facto non-flat, not to mention that the cell lines used are in many cases animal-derived or irrelevant to the dental pulp cellular population composition.

In a previous study, a 3D dentin/pulp tissue analogue was developed, recapitulating the pulp and dentin components in a 3D culture set-up, and was used as a sophisticated 3D in vitro evaluation tool of cytotoxicity of two model resinous monomers (HEMA and TEGDMA) [26]. Taking a step forward, the present paper aims to evaluate the biological response of the 3D dentin/pulp tissue analogue to the application of commercially available adhesive resin cements, one containing HEMA, [Breeze ${ }^{\mathrm{TM}}$ (C1), (Pentron, Clinical Technologies, LLC, CT, USA)] and another containing TEGDMA, [SpeedCEMplus ${ }^{\mathrm{TM}}$ (C2), (Ivoclar-Vivadent, Schaan, Liechtenstein)] in conjunction with the presence of a typical Gram-oral bacteria wall component, i.e. lipopolysaccharide (LPS), that is commonly present in deep carious lesions. The biological endpoints of interest that are directly related to pulp physiological responses to external stimuli include cell viability and angiogenic differentiation potential of the cells within the dentin/pulp 3D tissue analogue. The research hypothesis was that there will be no difference between cells inside the control (nonstimulated) and the experimental (exposed to resin cements in presence/absence of LPS) dentin/pulp tissue analogues with respect to the above-mentioned biological properties.

\section{Materials and methods}

\subsection{Cell culture}

Dental Pulp Stem Cells (DPSCs) and Stem Cells from the Apical papilla (SCAP) were established from third molars of young healthy donors using the enzymatic dissociation method, as previously described [27]. After the donors had signed an informed consent form, samples were collected according to 


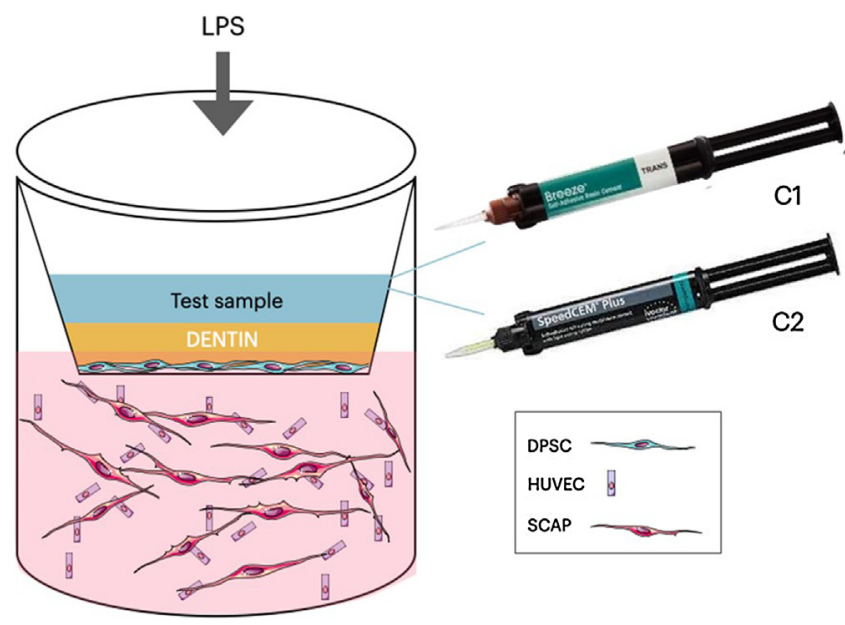

Fig. 1 - The 3D dentin/pulp tissue analogue which comprises of the upper and lower compartment, representing the dentin and pulp components respectively. The upper compartment consists of a layer of odontoblast-like cells derived from DPSCs and a disc of hTDM, while the lower compartment consists of HUVEC and SCAP seeded at a 3:1 ratio in Col-I/Fib hydrogels. The analogue received stimuli such as LPS and resin cement polymerized specimens (C1: Breeze ${ }^{\mathrm{TM}}$ and C2: SpeedCEMplus ${ }^{\mathrm{TM}}$ ).

the guidelines of the Institutional Review Board (Nr. 66/1806-2018). The teeth were disinfected and dissected across the cementum-enamel junction. DPSCs and SCAP cultures were established from the collected and separated dental pulp and apical papilla respectively, which were mechanically minced and digested in a collagenase type $\mathrm{I}(3 \mathrm{mg} / \mathrm{ml})$ and dispase II $(4 \mathrm{mg} / \mathrm{ml})$ solution (Invitrogen, Karlsruhe, Germany) for 1 $\mathrm{h}$ at $37^{\circ} \mathrm{C}$. The cells were expanded with a-MEM (Minimum Essential Media) culture medium (Invitrogen), supplemented with 15\% Fetal Bovine Serum-FBS (EU-tested, Invitrogen), 100 mM L-ascorbic acid phosphate (Sigma-Aldrich, Taufkirchen, Germany), 100 units/ml penicillin, $100 \mathrm{mg} / \mathrm{ml}$ streptomycin and $0.25 \mathrm{mg} / \mathrm{ml}$ Amphotericin B (all from Invitrogen) (=Complete Culture Medium-CCM) and incubated at $37^{\circ} \mathrm{C}$ in $5 \% \mathrm{CO}_{2}$. Passage numbers from 2 to 6 from at least three donors were used for all experiments with similar results. Human Umbilical Vein Endothelial Cells (HUVEC) were purchased (Lonza, Basel, Switzerland) and cultured on collagen I- (rat tail, BD Biosciences) coated culture vessels. HUVEC were expanded in M199 medium (Invitrogen) supplemented with Endothelial Cell Growth Supplement (ECGS, $30 \mu \mathrm{g} / \mathrm{ml}$, Sigma-Aldrich), heparin $(50 \mu \mathrm{g} / \mathrm{ml}$, Sigma-Aldrich) and 20\% FBS (=HUVEC medium).

\subsection{The $3 \mathrm{D}$ dentin/pulp tissue analogue preparation}

The 3D dentin/pulp tissue analogue used here has been extensively characterized and described in previous publication [26]. Briefly, it comprises of two compartments, namely the upper compartment, representing the dentin component and the lower compartment, representing the pulp (Fig. 1).
2.2.1. The upper compartment (the dentin analogue)

For the preparation of the upper compartment, DPSCs $(5 \times$ $105)$ were directly seeded on a microporous, semi-permeable membrane $(8 \mu \mathrm{m})$ of a cell culture insert (Millicell ${ }^{\circledR}$, Merck Millipore, Billerica, Massachusetts, U.S.A), underneath a human treated dentin disc. DPSCs were expanded in an odontogenic medium i.e. CCM, supplemented with $0.01 \mathrm{mM}$ dexamethasone disodium phosphate, $1.8 \mathrm{mM}$ monopotassium phosphate $\left(\mathrm{KH}_{2} \mathrm{PO}_{4}\right)$ and $5 \mathrm{mM}$ beta-glycerophosphate (all from Sigma-Aldrich), which was used to induce odontogenic differentiation of DPSCs and finally produce a coherent layer of odontoblast-like cells.

\subsubsection{Collagen-I/Fibrin (Col I/Fib) hydrogel preparation} (the pulp analogue)

For the establishment of the pulp analogue, HUVEC and SCAP cells were first co-cultured in 2D conventional culture flasks at a ratio of HUVEC:SCAP $=3: 1$, as described in previous work [26]. Briefly, for the HUVEC/SCAP co-cultures, HUVEC were pre-seeded in collagen I-coated polystyrene culture flasks in HUVEC medium, followed by the addition of the SCAP cells on top of the HUVEC monolayer $24 \mathrm{~h}$ later. The total cell concentration varied from 0.5 to $2 \times 106 \mathrm{cells} / \mathrm{ml}$ depending on the experimental procedure. In parallel, the HUVEC medium was changed to CCM medium, enriched with three additional supplements: recombinant human VEGFa (50 ng/ml, Invitrogen), Endothelial Cell Growth Supplement (ECGS, $30 \mu \mathrm{g} / \mathrm{ml}$, Sigma-Aldrich), and heparin $(50 \mu \mathrm{g} / \mathrm{ml}$, Sigma-Aldrich) (=CCM+++ medium). Another $24 \mathrm{~h}$ later, the cocultured HUVEC/SCAP were trypsinised and centrifuged. The resulting pellet was resuspended in a Col-I/Fib mix resulting in hydrogels, which represented the pulp analogues. Briefly, commercially available type I collagen solution (rat tail collagen I, Corning, Life Sciences Ltd, Kaiserslautern, Germany) at a starting concentration of $3.3 \mathrm{mg} / \mathrm{ml}$ in $0.02 \mathrm{~N}$ acetic acid was mixed with $1.3 \% 1 \mathrm{~N} \mathrm{NaOH}, 10 \% 10 \mathrm{x}$-concentrated PBS (Invitrogen), fibrinogen at a starting concentration of $10 \mathrm{mg} / \mathrm{ml}$ in PBS for the $3.5 \mathrm{mg} / \mathrm{ml}$-hydrogel or $20 \mathrm{mg} / \mathrm{ml}$ for the 5 $\mathrm{mg} / \mathrm{ml}$-hydrogel (Sigma-Aldrich), and thrombin at a starting concentration of $75 \mathrm{U} / \mathrm{ml}$ in $80 \mathrm{mM} \mathrm{CaCl}_{2}$ (Sigma-Aldrich). The volumes of collagen and fibrinogen solutions varied and were selected to provide two types of hydrogels with respect to total protein concentration i.e. $3.5 \mathrm{mg} / \mathrm{ml}$ and $5 \mathrm{mg} / \mathrm{ml}$. The final concentration of thrombin was $1.2 \mathrm{U} / \mathrm{ml}$ in both cases. Recombinant human VEGF (rhVEGF ${ }_{165}$, Invitrogen) at a final concentration of $50 \mathrm{ng} / \mathrm{ml}$ and protease inhibitor cocktail (1 mM PMSF, $0.1 \mathrm{mM}$ DTT, $10 \mu \mathrm{M}$ aprotinin, $10 \mu \mathrm{M}$ leupeptin, Sigma-Aldrich) at a final volume of $0.5 \%$ were also incorporated into the hydrogels.

\subsubsection{Preparation of the hTDM discs}

The human treated dentin matrices (hTDMs) were prepared from human extracted third molars after patient consent (ethics approval Nr. 66/18-06-2018), by axial sections generating one disk of $0.5 \mathrm{~mm}$ thickness per molar using an IsoMet low speed saw (Buehler, Lake Bluff, IL). The resulting hTDMs were further shaped in the form of discs $(6 \mathrm{~mm}$ in diameter) by using a circular metal template and highspeed dental handpieces and diamond burs under water irrigation. Dentin matrix treatment followed to remove the 
smear layer using decreasing concentrations of the chelating agent ethylene-diamine-tetraoxic-acid (EDTA), with intermediate steps of cleaning with distilled water in a sonicator, as previously described [27]. Before utilization, the hTDM discs were sterilized in $70 \%$ ethanol for 15 sec and then thoroughly rinsed with deionized water. They were then carefully adapted within the hanging culture insert. Their margins were sealed by dispersing a Dow Corning ${ }^{\circledR}$ high vacuum grease (Corning, Life Sciences Ltd, Kaiserslautern, Germany) using an insulin syringe to prevent medium leakage from the circumference of the hTDM.

\subsection{Preparation of adhesive resin cement specimens}

The two selected resin cements were both self-adhesive and selfcuring with light cure option. Breeze ${ }^{\mathrm{TM}}$ contained HEMA in its catalyst constituents while SpeedCEMplus ${ }^{\mathrm{TM}}$ contained TEGDMA in its base, more information on the two products are presented in Table 1 . To prepare identical specimens of the two resin cements (Breeze ${ }^{\mathrm{TM}}$ and SpeedCEMplus ${ }^{\mathrm{TM}}$ ), polyvinylsiloxane molds were prepared as follows: titanium disks of the desired dimensions $(6.5 \mathrm{~mm}$ in diameter and 2 $\mathrm{mm}$ in height), were immersed in polyvinylsiloxane (Heraeus Kulzer, Variotime, Hand-mix, Easy Putty, Hanau, Germany). The material was allowed to set according to the manufacturer's instructions, and the molds were allowed to dry for $15 \mathrm{~min}$ in ambient atmosphere. A solution for impression materials was used to disinfect the molds. Subsequently, the resin cements, Breeze ${ }^{\mathrm{TM}}$ (Pentron) (C1), and SpeedCEMplus ${ }^{\mathrm{TM}}$ (Ivoclar, Vivadent) (C2) were condensed into the molds, as per manufacturer's instructions. The materials used and their respective composition are listed in Table 1 . Sterile glass plates, spatulas, and resin restorative instruments were used to prepare the specimens. Both resin cements were allowed to set inside the molds for $12 \mathrm{~min}$, finally leading to cylindrical specimens $(6.5 \times 2 \mathrm{~mm})$ with a total surface area of approximately $1 \mathrm{~cm}^{2}$. Afterwards, the specimens were UV-sterilized $(245 \mathrm{~nm})$ for $30 \mathrm{~min}$ in a laminar flow cabinet (Safemate Vision Class II 1.2 m Biological Safety Cabinet, Thermo Fisher Scientific, Waltham, U.S.A). A certain number of specimens $(n=36)$ for Breeze ${ }^{\mathrm{TM}}$ and $(\mathrm{n}=36)$ for SpeedCEMplus ${ }^{\mathrm{TM}}$ were used for direct contact experiments (for the real-time PCR analysis), while other specimens $(n=30)$ for Breeze ${ }^{T M}$ and $(n=30)$ for SpeedCEMplus ${ }^{\mathrm{TM}}$ were used for eluate preparation to be used for indirect experiments (viability assays-MTT and live/dead staining followed by confocal microscopy).

\subsection{Preparation of adhesive resin eluates}

Breeze $^{\mathrm{TM}}$ (C1) or SpeedCEMplus ${ }^{\mathrm{TM}}$ (C2) discs, were incubated in culture medium (alpha MEM, Biosera) supplemented with $100 \mathrm{mM} \mathrm{L-ascorbic} \mathrm{acid} \mathrm{phosphate} \mathrm{(Sigma-Aldrich),}$ 100 units $/ \mathrm{ml}$ penicillin, $100 \mathrm{mg} / \mathrm{ml}$ streptomycin, $0.25 \mathrm{mg} / \mathrm{ml}$ Amphotericin B and Fetal Bovine Serum (FBS 15\%) (Complete Culture Medium-CCM) (all from Invitrogen, Thermo Fisher Scientific), for $72 \mathrm{~h}$ at $37{ }^{\circ} \mathrm{C}, 5 \% \mathrm{CO}_{2}$, and $100 \%$ humidity. The total surface to volume ratio was $1 \mathrm{~cm}^{2} / \mathrm{ml}$, according to ISO 10993/12 [28]. After 3 days, the culture medium was collected and syringe-filtered sterilized through a $0.2 \mu \mathrm{m}$ filter. The collected eluates were used for the indirect contact experiments.

\subsection{Evaluation of the shear modulus of the 3D systems}

For the evaluation of the mechanical properties of the 3D hydrogels, samples with $5 \times 10 \hat{5}$ total HUVEC: SCAP cells at a 3:1 ratio were evaluated at $1,3,7$ and 14 days by measuring the shear modulus. Samples of the natural human pulp and Col-I/Fib hydrogels without cell incorporation were used as positive and negative controls respectively. The hydrogels were poured into the wells of a collagen I- coated 24 well-plate and incubated at $37^{\circ} \mathrm{C}$ in $\mathrm{CCM}+++$ up to the time point of observation. The hydrogels were then retracted from the walls of the wells, washed with PBS and fixed in $10 \%$ formalin solution in PBS prior to the oscillatory shear measurements. A Physica MCR-501 (Anton Paar, Austria) stress-controlled rheometer with an 8,10 - or 12-mm Parallel Plate geometry was used depending on sample amount. The temperature control was achieved through a Peltier Unit and the temperatures used were $25^{\circ} \mathrm{C}$ and $37^{\circ} \mathrm{C}$. The oscillatory measurements consist of an input oscillatory strain signal (of the form $\sin (\omega t)$ ) and recording the output stress signal produced from the response of the material. To characterize the material properties at equilibrium, a small amplitude oscillatory signal is used to record the linear response of the material. This is called the Linear Viscoelastic Regime (LVE), determined through a Dynamic Strain Amplitude Sweep test, and defined as the regime in which the moduli have no dependence on the strain amplitude. A strain amplitude in the LVE was used for the Dynamic Frequency Sweep Tests (DFST). The DFST were conducted for constant strain amplitude and angular frequencies ranging from $0.1 \mathrm{rad} / \mathrm{s}$ to $100 \mathrm{rad} / \mathrm{s}$. The angular frequency dependence of both Storage Modulus (G') and Loss Modulus (G") was negligible in this regime exhibiting the solid-like character of the cross-linked by formalin networks. The shear modulus was determined as the storage modulus at $1 \mathrm{rad} / \mathrm{s}$, arbitrarily, since the Storage Modulus is independent of frequency. Sealing was achieved with a sealing ring and by covering the sample with low viscosity $(4.6 \mathrm{cP})$ silicon oil (PDMS) in order to avoid evaporation of water while measuring. The shear modulus for each sample was obtained as the average of five different sample loadings on the rheometer. The standard deviation was used to determine the error bar of the experimental procedure.

\subsection{Evaluation of the biological effects of resin cements and/or oral bacteria components on the established 3D culture dentin/pulp tissue analogue}

\subsubsection{Sprouting assay inside the 3D Col I/Fib hydrogel} representing the pulp component

The Col I/Fib hydrogels $(3.5 \mathrm{mg} / \mathrm{ml})$ encapsulating the HUVEC/SCAP cells $(5 \times 10 \hat{5} /$ hydrogel) were prepared as described in Section 2.2.2. The cells were allowed to adapt for $24 \mathrm{~h}$ in CCM+++. The medium was then removed, and the hydrogels were stimulated with LPS (from Escherichia coli, Sigma-Aldrich, Taufkirchen, Germany) $(1 \mu \mathrm{g} / \mathrm{ml})$ for $2 \mathrm{~h}$ at 37 ${ }^{\circ} \mathrm{C}$, under normoxic conditions $\left(20 \% \mathrm{O}_{2}\right)$. After the stimulation, the medium was changed to $\mathrm{CCM}+++$ in presence of disc 
Table 1 - Brands, chemical compositions and manufacturers of the two resin cements employed for the experiment, Breeze $^{\mathrm{TM}}$ (Pentron) (C1) and SpeedCEMplus ${ }^{\mathrm{TM}}$ (Ivoclar, Vivadent) (C2).

\begin{tabular}{|c|c|c|c|}
\hline Materials & Composition & LOT & Manufacturer \\
\hline Breeze $e^{\mathrm{TM}}$ & Base: 7,7,9(or 7,9,9)-trimethyl- & 6918749 & Pentron, Clinical Technologies, \\
\hline Self-adhesive dual cure & $\begin{array}{l}\text { 4,13-dioxo-3,14- } \\
\text { dioxa-5,12-diazahexadecane- } \\
\text { 1,16-diyl bismethacrylate, } \\
\text { 2,2'-ethylenedioxydiethyl } \\
\text { dimethacrylate, Phosphorus } \\
\text { pentoxide. } \\
\text { Catalyst: 2-[(2-methyl-1- } \\
\text { oxoallyl)oxy]ethyl } \\
\text { 1,3-dihydro1,3- } \\
\text { dioxoisobenzofuran-5- } \\
\text { carboxylate, 2-hydroxyethyl } \\
\text { methacrylate, Dibenzoyl } \\
\text { peroxide. }\end{array}$ & Ref N97B & LLC, CT, USA \\
\hline $\begin{array}{l}\text { SpeedCEMplus }{ }^{\mathrm{TM}} \\
\text { Self-adhesive self-curing with } \\
\text { light cure option }\end{array}$ & $\begin{array}{l}\text { Base: urethane dimethacrylate, } \\
\text { triethylene glycol } \\
\text { dimethacrylate, polyethylene } \\
\text { glycol dimethacrylate. } \\
\text { Catalyst: ytterbium trifluoride, } \\
\text { urethane. dimethacrylate, } \\
\text { methacrylated phosphoric acid } \\
\text { ester, polyethylene glycol } \\
\text { dimethacrylate, 1,10-decandiol } \\
\text { dimethacrylate, dibenzoyl } \\
\text { peroxide. }\end{array}$ & $\begin{array}{l}\text { Lot ZOOHC2 } \\
\text { Ref \#681612WW }\end{array}$ & $\begin{array}{l}\text { Ivoclar-vivadent, Schaan, } \\
\text { Liechtenstein }\end{array}$ \\
\hline
\end{tabular}

specimens of either $\mathrm{C} 1$ or $\mathrm{C} 2$, to determine the effect of the resin cement on the development of a $3 \mathrm{D}$ capillary-like network. After three days, a live/dead staining of the dentin/pulp tissue analogues was performed by cell labelling with Calcein AM and Ethidium homodimer/EthD-1, respectively, for $30 \mathrm{~min}$ at room temperature (RT). The pulp tissue analogues were observed under a confocal microscope (EZ-C1 Nikon, Tokyo, Japan). Approximately 20-30 serial sections were obtained with the green laser $(515 \mathrm{~nm})$ and the red laser $(650 \mathrm{~nm})$ and then the $z$-stacked images were produced. Hydrogels without exposure to resin cement specimens were used as controls.

\subsubsection{Evaluation of the effects of LPS and/or resin cement eluates on cell viability (MTT assay)}

The effects of LPS and/or resin cement eluate treatment on the viability of the HUVEC/SCAP co-cultured cells incorporated into the Col-I/Fib hydrogels representing the pulp component in comparison with 2D HUVEC/SCAP co-cultures at the same ratio were comparatively evaluated by means of the MTT assay. Both 2D and 3D co-cultured HUVEC/SCAP cells were exposed to the eluates of C1 or C2 resin cements, with or without previous exposure to $1 \mu \mathrm{g} / \mathrm{ml}$ LPS ( \pm LPS) for $2 \mathrm{~h}$. In the 2D system, the HUVEC/SCAP cells were plated in 96-well plates at $10 \hat{4}$ cells/well in six replicates for each sample $(n=6)$. In the 3D system, the HUVEC/SCAP cells were incorporated within the $3.5 \mathrm{mg} / \mathrm{ml}$-Col I/Fib hydrogel, at $100 \mu \mathrm{l}$ per hydrogel in four replicates per sample $(n=4)$, at $106 \hat{~ c e l l s ~} / \mathrm{ml}$, under normoxic conditions. After 24 and $72 \mathrm{~h}$ the MTT assay was performed to comparatively evaluate cell viability of the $2 \mathrm{D}$ vs. 3D co-culture systems. Briefly, at each time-point MTT (at $0.5 \mathrm{mg} / \mathrm{ml}$ final concentration) was added into each well and incubated for 4 $\mathrm{h}$ at $37^{\circ} \mathrm{C}$ and $5 \% \mathrm{CO}_{2}$. Then, the culture supernatants were discarded, and DMSO was added to each well to dissolve the insoluble formazan crystals. The absorbance was measured 1 $\mathrm{h}$ later against blank (DMSO) at a wavelength of $545 \mathrm{~nm}$ and a reference filter of $630 \mathrm{~nm}$ using a microplate reader (Epock, Biotek, Biotek instruments, Inc, Vermont, U.S.A). The results were calculated as the averaged absorbance of all replicates and then expressed in the form of $\%$ percentage of the control (i.e. cells not exposed to LPS but exposed for $2 \mathrm{~h}$ to the serumfree media). The optical density (OD) of cell-free hydrogels was subtracted from all obtained values.

\subsection{Evaluation of the impact of resin cement- and/or LPS treatment on the angiogenic properties of the $3 D$ culture system}

After studying the effect of the adhesive resin cements with or without the addition of LPS, in terms of cell viability within 3D hydrogels, we aimed to test their effect on the angiogenic properties of these cells in the fully assembled 3D dentin/pulp tissue analogue [26]. In this analogue, the Col-I/Fib hydrogel within the 24-well plate received the stimuli through the hanging culture insert containing the layer of odontoblast-like cells, the treated dentin disk, and the C1 or C2 specimens as set materials, with or without simultaneous presence of LPS. To analyze the expression of angiogenesis-related genes under the influence of resin cements (C1 or C2) ( \pm LPS) on the 3D culture system, HUVEC/SCAP cells were seeded at $2 \times 10 \hat{6}$ cells/hydrogel at a 3:1 ratio, and the upper compartment comprised of a layer of $5 \times 10 \hat{5}$ odontoblast-like cells.

These samples were first stimulated with LPS $(1 \mu \mathrm{g} / \mathrm{ml})$ for $2 \mathrm{~h}$ and then exposed to the respective resin cement disc specimens, $\mathrm{C} 1$ or $\mathrm{C} 2$ for up to 7 days. At 1,3 and 7 
Table 2 - Primers designed for the Real-time PCR analysis of angiogenic differentiation-related genes and the respective amplicon sizes of the PCR products.

\begin{tabular}{llll} 
Gene symbol & Forward (5'-3') & Reverse (5'-3') & Amplicon size (bp) \\
\hline VEGFA & AGGAGGGCAGAATCATCACG & CCAGGGTCTCGATTGGATGG & 80 \\
VEGFR2 & CGGTCAACAAAGTCGGGAGA & CAGTGCACCACAAAGACACG & 123 \\
Ang-1 & ATGGGGGAGGTTGGACTGTA & TGCCTCTGACTGGTAATGGC & 151 \\
Tie-2 & AGGACGTGTGAGAAGGCTTG & GTGGCACAGGAACACCCATA & 128 \\
PECAM-1 & GTCAAGCCTCAGCACCAGAT & GCTGGTACTCTGCAGTGGTT & 175 \\
B2M & TGTCTTTCAGCAAGGACTGGT & ACATGTCTCGATCCCACTTAAC & 138 \\
SDHA & GCATGCCAGGGAAGACTACA & GCCAACGTCCACATAGGACA & 127 \\
\hline
\end{tabular}

days of exposure (D1, D3, and D7), samples were retrieved for RNA isolation. Briefly, the medium was removed from the wells, and the cell-containing hydrogels were washed twice with PBS. Then, the hydrogels were subjected to enzyme digestion using $0.25 \%$ trypsin/1 mM EDTA for 5-10 min at $37{ }^{\circ} \mathrm{C}$. The collected samples were then centrifuged at 115 $\mathrm{g}$ for $5 \mathrm{~min}$, and the supernatant was discarded. RNA isolation was performed using a commercially available RNA isolation kit (Macherey Nagel, Düren, Germany) according to the manufacturer's instructions. The total RNA obtained was subsequently reverse transcribed ( $0.5 \mu \mathrm{g} /$ sample) using a superscript first-strand synthesis kit (Takara, Takara Bio USA, Inc, Mountain View, CA), according to manufacturer's instructions. Reactions were performed using SYBR-Select PCR Master Mix (Applied Biosystems, Foster City, CA) in a Step One Plus thermal cycler (Applied Biosystems). All reactions started with two initial incubation steps at $50{ }^{\circ} \mathrm{C}$ for 2 min and at $95^{\circ} \mathrm{C}$ for 2 min and were followed by 40 cycles of PCR, comprising denaturation for $15 \mathrm{sec}$ at $95^{\circ} \mathrm{C}$ and annealing/extension for $1 \mathrm{~min}$ at $60^{\circ} \mathrm{C}$. Primers were designed using the Primer-Blast software from the NCBI nucleotide sequence database (http://www.ncbi.nlm.nih.gov/BLAST) for the following angiogenesis-related genes: VEGFa, VEGFR-2, ANGPT-1, TIE-2 and PECAM-1 (Table 2). The results were adjusted by amplification efficiency (LinRegPCR) and were normalized against two housekeeping genes (succinate dehydrogenase complex, subunit A/SDHA and beta-2-microglobulin-B2M).

\subsection{Statistics}

All experiments were performed in 3-6 replicates and repeated at least three times. Statistical analysis of the biological experiments was performed by two-way analysis of variance (ANOVA) and multiple comparisons between groups by Tukey's and Sidak's post-hoc tests. Normal distribution was confirmed by Kolmogorov-Smirnov normality tests. Data were expressed as means ( \pm standard deviation; SD). All analyses were performed using Prism 6.0 Software (GraphPad, CA, U.S.A) at two levels of statistical significance, i.e., ${ }^{*} p<0.05$ and ${ }^{* *} p<0.01$.

\section{Results}

\subsection{Mechanical properties-evaluation of hydrogel stiffness in comparison with the natural pulp}

The shear modulus of the hydrogel with the lower total protein content $(3.5 \mathrm{mg} / \mathrm{ml})$ increased from D1 $(2.6 \mathrm{kPa})$ through D7 (6
$\mathrm{kPa}$ ), showing increasing stiffness, where the values remained similar and relatively constant up to D14 (5 kPa). Regarding the hydrogel with the higher protein content $(5 \mathrm{mg} / \mathrm{ml})$, the shear modulus was constant around $5 \mathrm{kPa}$ during the first week in culture, while there was an increase up to $100 \mathrm{kPa}$ on D14, which exceeds by far the value obtained for the natural pulp $(15 \mathrm{kPa})$. As the lower compartment of the final 3D assembly was aiming to represent a pulp analogue, the hydrogel with the values consistently close to the shear modulus of the natural pulp ( $3.5 \mathrm{mg} / \mathrm{ml}$ hydrogel) was selected to be used in the rest of the assays (Fig. 2A), which would be critical for those lasting more than seven days, such as the gene expression analysis. The DFSTs in Fig. 2B and C suggest that the samples of both hydrogel concentrations are highly elastic [29] with the storage modulus ( $G$ ') much larger (more than one decade) than the loss modulus (G") and almost independent of frequency in the whole range of angular frequencies measured.

\subsection{Assessment of the biological effects of resin cement- and/or LPS treatment on the dentin/pulp tissue analogue compared to conventional $2 \mathrm{D}$ cultures}

\subsubsection{Assessment of cell viability in the lower compartment after resin cement- and/or LPS treatment (MTT assay)}

An overall increase in cell viability was observed after the application of resin cements, C1 and C2, with or without previous treatment with LPS ( \pm LPS) on the co-cultures of HUVEC/SCAP in 2D monolayers. None of the tested conditions proved cytotoxic to the cellular populations in the 2D setup, as all values were similar or higher compared to the control values at all time-points regardless of the applied resin cement and/or LPS co-treatment. A statistically significant increase in cell metabolic activity compared to the same-day control without LPS, was observed only for $\mathrm{C} 1$ at $24 \mathrm{~h}$ in both presence or absence of LPS co-treatment ( $\mathrm{C} 1-, p<0.01$ and $\mathrm{C} 1+, p<0.05$ after $24 \mathrm{~h}$ ). The increased metabolic activity caused by $\mathrm{C} 1$ without LPS (C1 -: $134.2 \% \pm 7.4, p<0.01)$ at $24 \mathrm{~h}$ compared to the control, was statistically higher than the same condition at 72 $\mathrm{h}(\mathrm{C} 1-72 \mathrm{~h}: 114.1 \% \pm 12.2, p<0.01)$ and the same resin cement with the addition of LPS at the same time point ( $C 1+: 114.0 \%$ \pm 8.1 at $24 \mathrm{~h}, p<0.01$ ). Overall, the high cellular viability was maintained in $\mathrm{C} 1+$ cultures at $72 \mathrm{~h}$, but without significant differences compared to the control of the same time-point (control - at $72 \mathrm{~h}$ ), while C2 + cultures reached statistically significant increase in cell metabolic activity (C2 +: $112.0 \pm 10.1$, $p<0.05$ ) compared to the same time-point (control + at $72 \mathrm{~h}$ ) (Fig. 3A). 

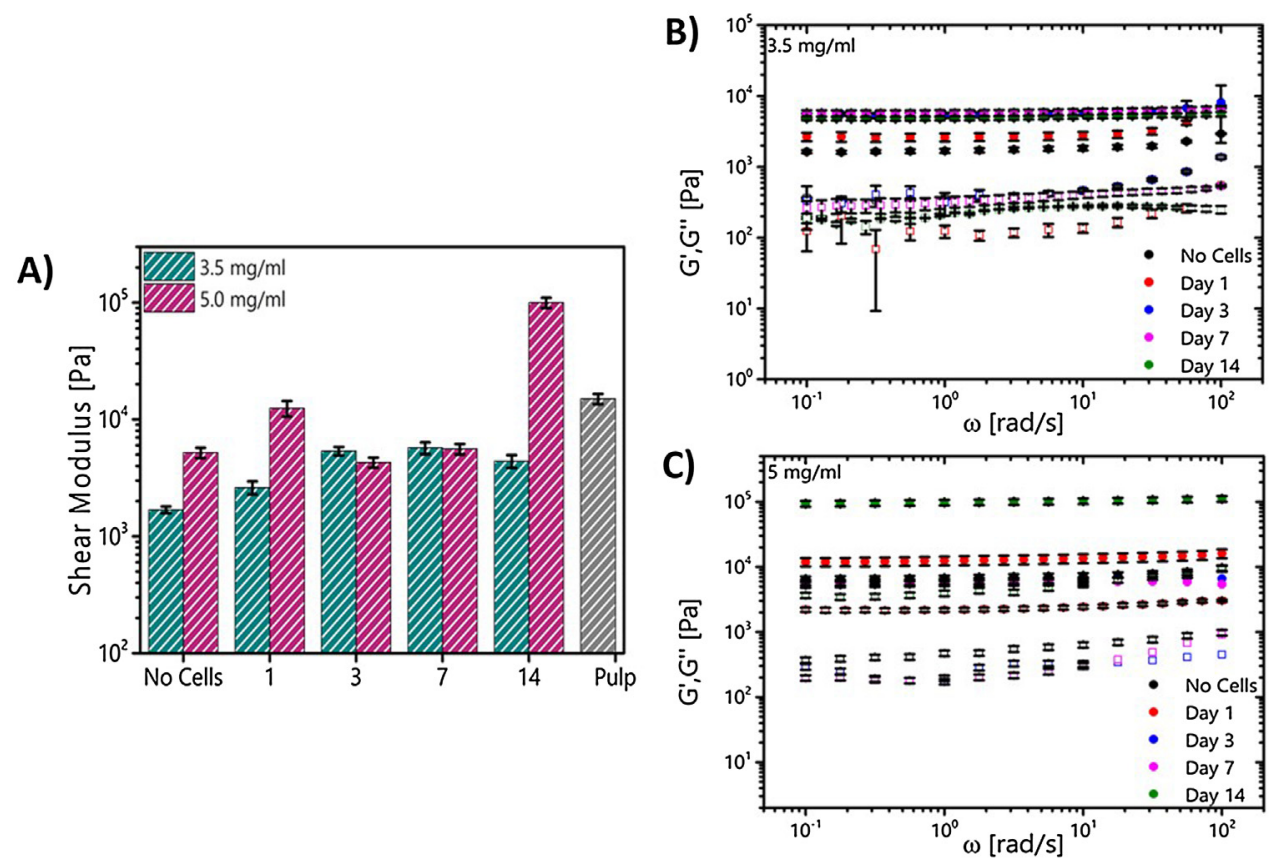

Fig. 2 - Evaluation of the mechanical properties of Col-I/Fib hydrogels at 1, 3, 7 and 14 days by measuring the shear stress modulus. (A) Green and pink columns represent Col-I/Fib hydrogels of $3.5 \mathrm{mg} / \mathrm{ml}$ and $5 \mathrm{mg} / \mathrm{ml}$ total protein content respectively. Samples of the natural human pulp (grey column) and Col-I/Fib hydrogels without cell incorporation (No Cells) and were used as positive and negative controls respectively. (B) Dynamic Frequency Sweep measurement for all Col-I/Fibrin samples with the concentration of $3.5 \mathrm{mg} / \mathrm{ml}$, and (C) of $5.0 \mathrm{mg} / \mathrm{ml} \mathrm{samples.} \mathrm{In} \mathrm{all} \mathrm{graphs} \mathrm{the} \mathrm{error} \mathrm{bars} \mathrm{are}$ determined from the standard deviation of five independent measurements.

When the resin cements were applied to the HUVEC/SCAP co-cultures in a 3D arrangement within Col-I/Fib hydrogels, with or without LPS co-treatment, the results were similar to those observed with the 2D arrangement, regarding the highest cell metabolic activity which was observed with C1 without LPS (C1 -: $158.0 \% \pm 3.3, p<0.01$ at $72 \mathrm{~h}$ ). The high values obtained for C1 - were significantly higher than their equivalent with the addition of LPS (C1+) at both time points $(p<$ 0.01 for both 24- and $72 \mathrm{~h}$ ). Worthy of mentioning was the significant recovery regarding $\mathrm{C} 2$ + treatment, where viability increased significantly at $72 \mathrm{~h}(\mathrm{C} 2+: 111.1 \% \pm 22.4)$ compared to the same treatment at $24 \mathrm{~h}(\mathrm{C} 2+: 79.3 \% \pm 8.0, p<0.05)$ (Fig. 3B).

\subsubsection{Assessment of cell viability in the lower}

compartment after resin cement- and/or LPS treatment (Live/dead fluorescent staining)

Live/dead fluorescent staining of the pulp analogue (lower compartment) performed at $72 \mathrm{~h}$, confirmed the resin cementand LPS treatment- dependent effects on cellular viability of the above described results of the MTT assay. This was evidenced by representative confocal microscopy figures depicting LPS/resin cement co-treated HUVEC/SCAP co-cultures, seeded within Col-I/Fib hydrogels (Fig. 4). At 72 $\mathrm{h}$ of co-treatment the control with or without LPS, showed the least number of dead (stained red with EthD-1) cells $(1.8 \%$ and $2.9 \%$ respectively), compared to C1/LPS (15.0\%) and C2/LPS (16.7\%). The cell arrangement of C2/LPS was optimal, indicating that cells were able to maintain cell viability $(83.3 \%)$ and to form capillary-like networks (Fig. 4D). In contrast, in the C1/LPS co-treatment group, the cellular morphology was damaged, as observed with sparsely allocated, rounded, but still living (green) cells, that turned red with time, due to intercalation of the EthD-1 dye into their DNA, after cell membrane damage and probably also due to cell death induced by the tested cement (Fig. 4C). These results are in line with those of the MTT assay described above. Indeed, at $72 \mathrm{~h}$, the cell viability values for the control/LPS group were significantly higher than C1/LPS $(p<0.01)$ and lower than C2/LPS although the latter was not statistically significant.

\subsection{Evaluation of the effects of resin cement- and/or} LPS treatment on the angiogenic potential of the lower compartment (real-time PCR analysis)

Exposure of the HUVEC/SCAP cells of the lower compartment housing the Col-I/Fib hydrogel, to specimens of adhesive resin cements, with or without co-treatment with LPS, had a pronounced impact on the expression of angiogenic markers. A general observation is that the upregulation of the evaluated markers (VEGF, ANGPT-1) was more pronounced in LPS + compared to the LPS-cultures, in C2-compared to the C1-tretated cultures, and increased with the progress of time (higher on D7 than on D3). Their respective receptors (VEGFR-2, Tie-1) showed a reciprocal inverse relation in their expression. The intercellular junctional molecule, PECAM-1, did not show significant fluctuations compared to the control except a distinct peak in C2 + sample on D7. (Fig. 5 A-E). 

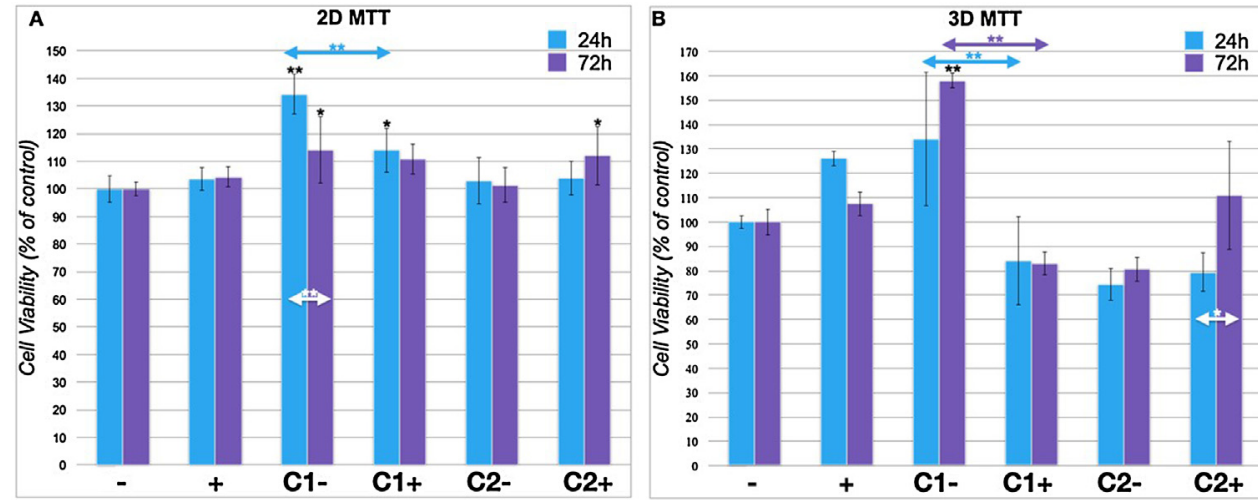

Fig. 3 - Cytotoxic effects of LPS and/or resin cement specimens, Breeze ${ }^{\mathrm{TM}}$, Pentron (C1) or SpeedCEMplus ${ }^{\mathrm{TM}}$, Ivoclar-Vivadent (C2) on the 2D (A) or 3D (B) HUVEC/SCAP co-cultures, evaluated by MTT assay 24 and $72 \mathrm{~h}$ post exposure. Black asterisks indicate statistically significant differences compared to the respective control (- LPS) cultures $\left({ }^{*} p<0.05,{ }^{* *} p<0.01\right)$. Red and grey horizontal arrows represent statistically significant differences at 24 or $72 \mathrm{~h}$ respectively for the same resin cement between LPS (-) and LPS (+)-treated cultures.
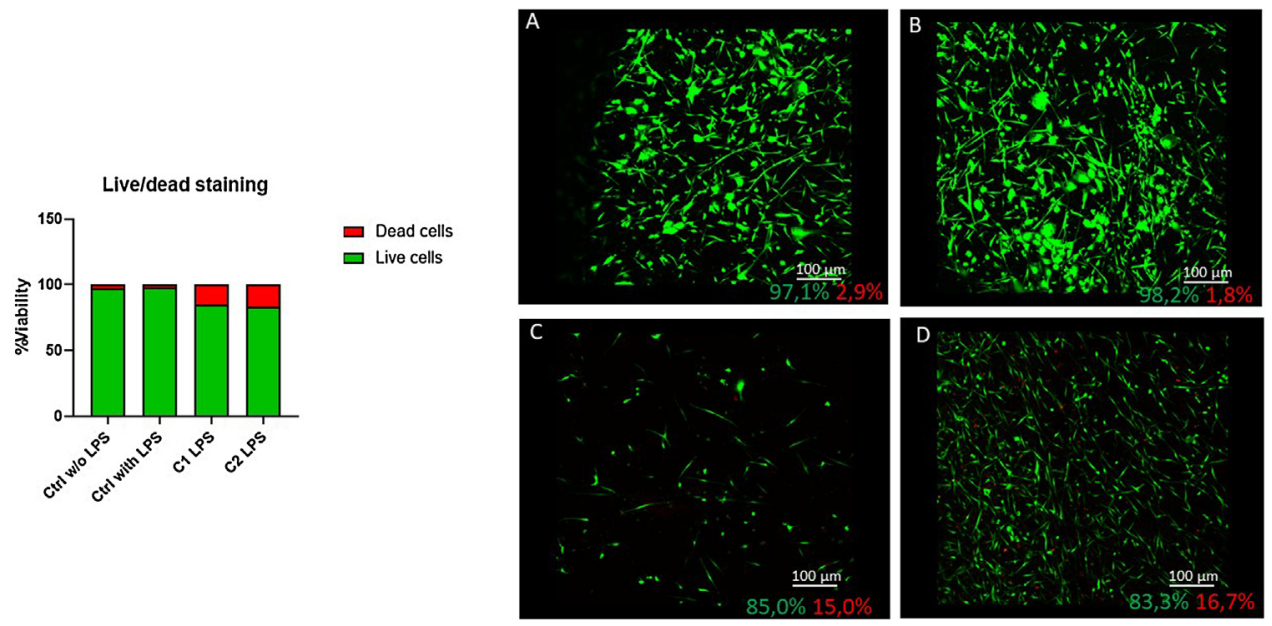

Fig. 4 - Live/dead fluorescent staining with Calcein AM and EthD-1, depicting cytotoxic effects of control-LPS (A), control + LPS (B), C1 + LPS (C) and C2 + LPS (D), on the of the HUVEC/SCAP co-cultures of the lower compartment (scale bars: $100 \mu \mathrm{m}$ ). The green and red percentages below the scale bar of each image represent the live and dead cells respectively. The bar chart is a graphical representation of this percentages of live/dead cells of the four groups.

In more specific, VEGF expression (Fig. 5A) was significantly (compared to control of D1 and compared to the same-day controls) upregulated on D3 and D7, after exposure to both LPS and C2 (D3: C2 +: $14.1 \pm 0.1$-fold, $p<0.01$ and D7: C2 +: 23.1 \pm 4.4 -fold, $p<0.01$ ), a behavior similar to that of $\mathrm{C} 1$ with the addition of LPS on D7 (D7: C1 +: $18 \pm 2.9$-fold, $p<0.01$ ).

Regarding the expression of the receptor VEGFR-2 (Fig. 5B), no significant differences were observed compared to control of D1. Although a general trend for downregulation was obvious at both time-points (D3 and D7), which was more extensive in C2, the only statistically significant difference was observed between $\mathrm{C} 2+$ on D7 with the same-day control, where there was a marked down-regulation (D7 control: $1.2 \pm 0.2$-fold and D7 C2+: $0.5 \pm 0.1$-fold, $p<0.01$ ).

When studying the expression of the components of the ANGPT-1/Tie-2 axis (Fig. 5C and D), it was shown that ANGPT-1 had a similar expression profile to VEGF for the C2+, group, meaning that significant (compared to the control of D1, as well as to the equivalent controls of D3 and D7) upregulation was detected at both time points (D3 C2 +: $6.6 \pm 0.3$-fold, $p<0.01$ and D7: C2 $+10.7 \pm 1.2$-fold, $p<0.01)$. Notably, the highest upregulation was achieved on D3, in C2-cultures (D3: C2 -: $14.6 \pm 3.3$-fold, $p<0.01$ ), which was also significantly higher than the control of D1, as well as the control of D3 ( $p$ $<0.01$ ). Expression of Tie-2 was significantly downregulated at both time-points, D3 and D7, irrespective of the adhesive resin cement applied or LPS stimulation, compared to the control of D1 $(p<0.01)$. The only exception was observed on D7 for the $\mathrm{C} 2$ + sample, where the expression of Tie-2 recovered up to the levels of the control of D1. Besides, this upregulation was significantly higher than the control of the same day $(p<0.01)$.

Lastly, expression of the endothelial cell adhesion molecule PECAM-1 (Fig. 5E), showed downregulation in a time-depend manner in the controls of D3 and D7, compared to D1 $(p<$ $0.05)$. The opposite was observed when C2 and LPS were used to stimulate the samples of D7, leading to a statistically sig- 

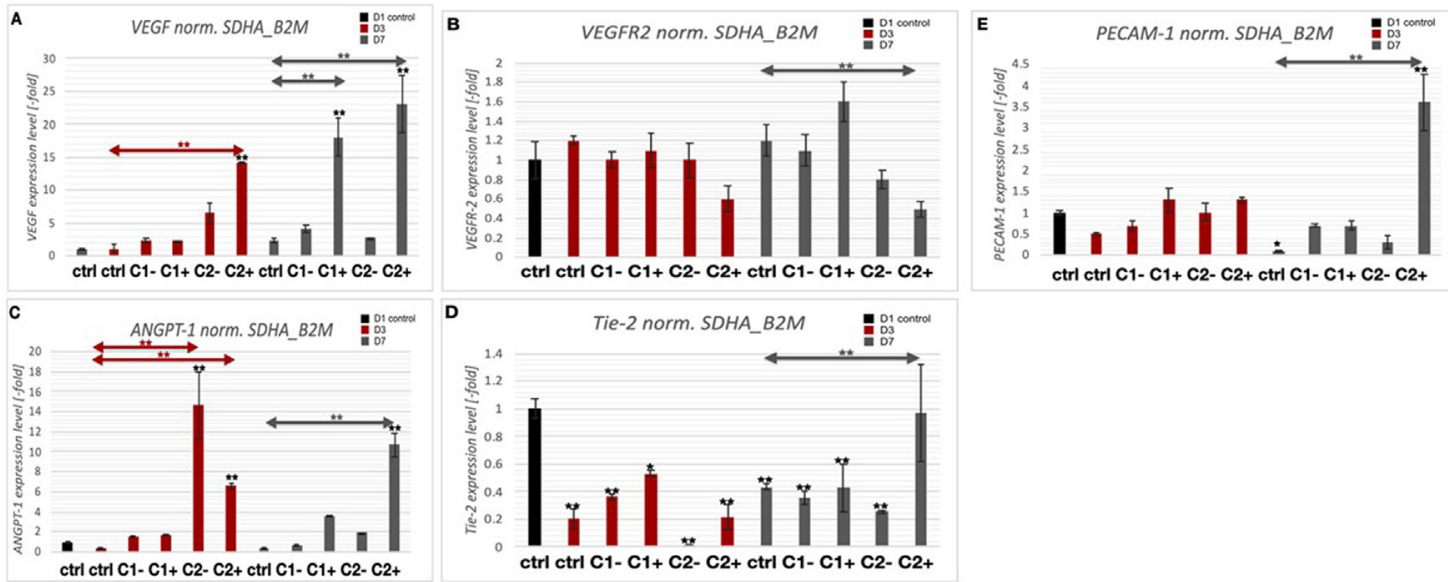

Fig. 5 - Impact of LPS and/or resin cement specimens' application on the expression of angiogenesis related markers (VEGF, VEGFR-2, ANGPT-1, TIE-2 and PECAM-1) (A-E) in 3D HUVEC/SCAP cocultures seeded 3D COL-I/FIB hydrogels representing the lower compartment. Angiogenesis-related gene expression was evaluated by Real-time PCR at D1, D3 and D7 after exposure to C1 or C2 with or without LPS [ $1 \mu \mathrm{g} / \mathrm{ml}$ for $2 \mathrm{~h}$ ] pretreatment. Values are means $( \pm \mathrm{SD})$ of three independent experiments in duplicates. Asterisks indicate statistically significant differences between treated samples and the D1 control cultures (*p < $\left.0.05,{ }^{* *} \mathrm{p}<0.01\right)$. Red and grey horizontal arrows depict statistically significant differences between treated samples and their respective controls for D3 and D7 respectively ( $\left.{ }^{*} \mathrm{p}<0.05,{ }^{* *} \mathrm{p}<0.01\right)$.

nificant increase compared to the control of D1 (D7 C2 +: $3.6 \pm$ 0.7-fold, $p<0.01)$ as well as to the same-day control $(p<0.01)$.

\section{Discussion}

This study has been implemented, in order to evaluate two commercially available products used in the final cementation of prosthetic rehabilitations-i.e. adhesive resin cements-using an organotypic 3D in vitro cytocompatibility assessment tool that has been previously described [26]. The particular model has been chosen among other models such as the tooth slice culture, the entire tooth culture, the tooth bud model, the customized cell perfusion chamber and other 3D dentin/pulp tissue analogue assemblies manufactured by tissue engineering. More details on available 3D dentin/pulp in vitro models may be sought in an extensive recent review paper [32]. The present model did not require expensive laboratory equipment, it was easy to put together, and it was readily reproducible. Also, it was possible to monitor the tissues (dentin/pulp tissue analogue) separately, although they were acting in synergy within the fully assembled tissue analogue. After the introduction of external stimuli to this dentin/pulp tissue analogue, no significant cytotoxic effects were observed, while C1 induced stimulation $(p<0.01)$ of cell proliferation $(158.0 \pm 3.3 \%, 72 \mathrm{~h})$, while pre-stimulation with LPS attenuated this effect. C2 $( \pm$ LPS) caused minor reduction of viability $(15-20 \%, 24 \mathrm{~h})$ that recovered at $72 \mathrm{~h}$ for the LPS+ group. Both cements induced upregulation of VEGF, ANGP-1, and downregulation of the respective receptors VEGFR-2 and Tie-1; thus, rejecting the research hypothesis.

It may be admitted that HUVEC and dental MSC co-cultures do enhance the regenerative procedure resulting in superior products promoting cell survival secretion of angiogenic factors which may induce vessel-like structure formation [33].
Also more general benefits of co-cultures may be the reduction in cell de-differentiation, as mentioned for chondrocytes, which has been attributed to trophic factors produced by the MSCs [34]. On the other hand, SCAP, are known to offer superior regenerative and angiogenic properties than other dental tissue-derived MSC $[35,36]$. This was the reason of employing both SCAP and DPSCs in our experimental setup, although the two populations have many similarities, because SCAP are supposedly superior in angiogenic properties than DPSC. Since the aim was to recreate a pulp analogue in the lower compartment it is clear that these choices were significant for the final purpose.

In order to provide a three-dimensional microenvironment to recapitulate natural ECM a Col-I/Fib hydrogel for embedding the co-cultured cells was applied. Several materials have been employed for the realization of an ECM analogue of the dental pulp, such as fibrin, collagen, alginate, and GelMA hydrogels [37-39]. Among the plethora of available materials and their combinations, it seems that natural materials prove to be more suitable for the regeneration of pulp-like tissues [40]. Collagen fibrils, type I and III, are among the well identified pulp intercellular matrix components [41]. Galler et al., comparing among polyethylene glycol, self-assembling peptides and natural materials, such as collagen and fibrin, revealed that natural materials - especially fibrin - offered higher cellular viability, improved scaffold degradation, soft tissue formation, vascularization and odontoblast-like differentiation, both in vitro and in vivo [42]. In another study, the incorporation of fibrin was beneficial compared to the utilization of collagen only, in terms of vasculogenesis [43].Thus, these two natural materials were chosen in combination for the present experimental set-up as well.

This paper proposes the preparation of a pulp analogue in a simple mixing procedure as an affordable option which does not demand special equipment. Over a decade ago, Engler 
et al. observed that apart from the dimensionality, another important aspect was the microenvironment and in particular stiffness of the hydrogel, influencing the stem cell fate [45]. In other words, the resemblance to the original tissue-the dental pulp in this case - is desirable when in vitro studies are implemented, in order to closely mimic the in vivo condition by ordering a phenotypic commitment of MSCs to the desired target tissue. A previous report indicated that chitosan/alginate scaffolds loaded with DPSCs significantly increased the storage modulus and elastic response compared to cell-free scaffolds, obtaining values similar to those of native temporomandibular joint disc [46], while another study reported on a significant increase in the stiffness of chitosan/gelatin scaffolds loaded with BM-MSCs with storage modulus values of $2 \mathrm{MPa}$ on day 7, compared to $0.5 \mathrm{MPa}$ on day 0 , following a drop at $0.8 \mathrm{MPa}$ on day 14 , possibly attributed to the increase of specific ECM proteases gene expression observed [47]. Having this in mind, in this paper, the stiffness of two hydrogel compositions were compared to the natural human dental pulp. The shear modulus of the natural dental pulp was found to be around $10 \mathrm{kPa}$ which is within the range of mesenchymal tissue stiffness, stiffer than fat tissue, less stiff than cartilage and quite similar to that of muscles $[48,49]$. The choice of $3.5 \mathrm{mg} / \mathrm{ml} \mathrm{Col-I/Fib} \mathrm{hydrogel} \mathrm{seemed}$ more appropriate as stiffness remained relatively constant through the experimental period and similar to the values obtained for the dental pulp, in contrast to the $5 \mathrm{mg} / \mathrm{ml}$ hydrogel which reached values which respond to those found in harder tissues or even tissue culture plastic surfaces $(>100 \mathrm{kPa})$ [48]. Other literature evidence is also in agreement with the utilization of lower total protein content, as the induced reduction in stiffness is beneficial to long-term vessel formation capability of the incorporated cells [43].

Matrix stiffness has also been investigated by other groups mentioning that different reactions in terms of increased cellular viability when cells were embedded in 3D matrices instead of direct contact tests, which may be associated to extensive cell-cell interactions due to the addition of the third dimension or even to the protective role of the matrix which is decreasing the capability of materials to penetrate through the 3D cell aggregates [50].

In the present study, the commercial products under investigation did not show statistically significant cytotoxic effects towards the pulp analogue. The reactions seen here, through the MTT assay show that the responses elicited by the

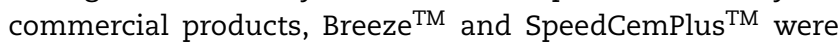
equivalent to those administered by low-monomer concentrations as reported for the same tool in previous publication i.e HEMA [ $1 \mathrm{mM}$ ] and TEGDMA [0.5 mM]. Studies have shown that the value of residual monomers released are in the order of a single-digit micromolarity, in particular TEGDMA released from SpeedCEMplus ${ }^{\mathrm{TM}}$, as evaluated by high-performance liquid chromatography (HPLC), was $6.18 \mu \mathrm{M}$ after three days of storage [51], which are much lower than those supplied in our previous experiment when evaluating solely monomers. This could be a possible explanation why no statistically significant cytotoxic effects were found in the present study since the released monomer concentrations were so low that could not elicit severe effects to the cells. From these we may deduce that any extremity, concentration-wise, may prove toxic for the regenerated tissue, but this may be misleading, as the commercially available product that is actually tested elicits no such reaction. This means that the proposed tool responded well, discriminating between a non-toxic product and the toxic high monomer concentrations in the previous publication [26]. The clinical consequences of the biodegradation of resin containing products are still poorly understood. More extensive study is required to assess the extent of the biological effects of the long-term release of biodegradation products to shorten the gap between laboratory research and clinical reports. Nonetheless, animal studies have been performed on the clearance, distribution, and elimination of TEGDMA and HEMA in guinea pigs. About $62 \%$ of TEGDMA [2] and about $64 \%$ of HEMA [52] was also exhaled $24 \mathrm{~h}$ post-injection in the jugular vein of guinea pigs showing that this is the major route of elimination. A small percentage (4\%) was detected various tissues, such as muscle, kidney, skin, blood and liver $24 \mathrm{~h}$ postinjection in the jugular vein [54]. All the detected doses were many-fold less than known toxic level, confirming that the in vivo situation is far from the severe toxic reactions reported in older laboratory studies. Thus, this in vitro model is in accordance with the in vivo observations where no severe toxic reactions have been detected.

In fact, exposure to the resinous cement eluates even managed to induce stimulation of metabolic activity at some occasions, for instance: 3D C1-LPS at $72 \mathrm{~h}$, to values significantly higher than the control, and for: 3D C2 + LPS at 72 $\mathrm{h}$, which showed significant increase in viability when compared to lower viability values observed at $24 \mathrm{~h}$. This cellular response is in accordance with other literature observations, where seven days post-incubation with dental cement specimens increased cell numbers compared to specimens added immediately after preparation could be observed [55]. At even longer incubation periods, the reduction in cytotoxicity increases over time to a level that it is no longer detectable at six weeks [56].

The viability values of this experiment may be granted also to the light irradiation of the dual cured resin samples. It has been shown, by chromatographic analysis, that light irradiation of HEMA- and TEGDMA- containing resin products (RelyX and Multilink Speed respectively) may reduce cytotoxicity and the amount of the eluted monomers, compared to results without light irradiation [57]. The same effect of lower cytotoxicity of dual-cured vs. self -adhesive cements was noted by Schmid-Schwap et al. and this was also explained by the fact that higher toxic effects are detected with more remaining unreacted substance [55]. Our results disagree with a study by Ulker et al., who tested the cytotoxicity potential of various commercially available resinous products in a 3D dentin barrier test, finding significant reduction (as low as $62 \%$ ) in cell survival by three out of the four materials under investigation [58]. These low values may be attributed to the test method, as in the present study the MTT test was implemented indirectly (using cement eluates), while in their study the specimens were directly introduced to the 3D culture system [58]. In this study the choice of indirect application of resin cements through eluates, instead of direct resin cement specimens introduction for the MTT, was chosen for reasons of homogeneity of the introduced stimuli, as the eluate from the 
resin cements was dispersed to the 6 replicates of the 2D and the 4 replicates of the 3D experimental setup.

The cytocompatibility of the Col-I/Fib hydrogel as an ECM has been previously evaluated by live/dead staining and confocal microscopy and it has proven to be a viable option for cell homing. The dentin/pulp tissue analogue supported cell viability and capillary-like network formation. The images obtained after the introduction of $\mathrm{C} 1$ and $\mathrm{C} 2$ resin cements had a validation role to the MTT assay. Indeed, it was shown than C2+ LPS had a stimulatory effect as cells were nicely arranged in a capillary like network with enhanced cellular viability. This may be supported by literature findings mentioning that the secretome of MSCs of dental origin may counteract the cytotoxic effect induced by low TEGDMA concentrations [0.25-0.5 mM] and even promote enhanced cellular viability [59]. Studies have also shown that the secretome of these cells may possess angiogenic and reparative properties to several tissues [60]. Literature data have shown that although low concentrations of TEGDMA and HEMA were able to reduce the LPS-induced release of pro-inflammatory cytokines (Il-1b and TNFa) [61], the same monomers were able to induce higher expression of VEGF, a cytokine able to promote wound healing and regulate angiogenesis [62]. This may partly explain the qualitative aspect of our live/dead staining data. Nonetheless, the cell lines employed here are of mesenchymal and endothelial origin and this field needs further exploration concerning the response to LPS and monomer stimulation. Both materials under investigation showed acceptable cytocompatibility after $30 \mathrm{~min}$ of UV radiation of the samples and triggered angiogenic responses within the tissue-engineered dentin/pulp tissue analogue, indicative of initiation of pulp repair processes as response to the released xenobiotics. Further to the cytocompatibility findings, the angiogenic potential was evaluated by real time PCR in the fully assembled dentin/pulp tissue analogue. This refers to the pulp analogue within the 24 well plate and the dentin analogue suspended over this pulp analogue within the hanging culture insert, composed of differentiated layer of odontoblast like cells and the treated-dentin disk. Numerous publications have dealt with incorporating the dentin barrier over an artificial pulp chamber in order to simulate the clinical scenario, with several variations, such as utilization of dentin slices of various thicknesses (100, 200, 300, 500, $700 \mu \mathrm{m})[21,63]$, cell seeding in 3D polyamide meshes instead of the initial 2D cell cultures on coverslips [21,64-66], using cells of human origin [67,68], and seeding cells in natural hydrogels, such as fibrin and collagen [68]. In general, these devices became more complex and sophisticated through the years, studying the perfusion of eluates from the dentin barrier $[20,69]$, introducing dynamic conditions in the system $[23,64,70]$ and even reproducing the dentin barrier itself [71]. The choice of $1 \mathrm{~mm}$ thick dentin slice is considered to reduce the potential cytotoxic effect of dental materials by $90 \%$ [72] but still, it may not be able to arrest the bacterial by-product propagation towards the pulp [30], since both the effects of resin by-products and bacterial components were to be evaluated-acting in synergy-a mutually acceptable solution had to be selected.

In this scenario the significant upregulation of the evaluated angiogenesis-related genes (VEGFa and ANGPT-1, and PECAM-1) was observed when the adhesive cements were introduced to the system, again more extenuated in the presence of C2+ LPS on D7. These results are in agreement with earlier studies mentioning that adhesive resins, as well as their monomers, may upregulate the VEGF expression by dental pulp cells, which is critical for the vascular homeostasis of the spatially restricted pulp chamber [73]. The upregulation of VEGF expression and its exogenous incorporation in the Col-I/Fib hydrogel may have depleted the respective receptor, VEGFR-2, as shown by the respective downregulation. This receptor is responsible for conformational alterations after binding with VEGF, which is a signal for a cascade finally leading to vascular network formation [74]. The positive angiogenic effect was also noted for ANGPT-1 after the addition of C2 at both time-points. ANGPT-1 after binding to its receptor Tie2 , activates intracellular signaling responsible for the integrity of the vessels, as well as for their decreased permeability with reinforced endothelial cell junctions [74]. Regarding the endothelial adhesion molecule, PECAM-1, other studies have also not detected significant changes when adhesive resins were applied on teeth prepared to receive crowns, when evaluated up to $48 \mathrm{~h}$ post-application [75]. On the other hand, the only significant upregulation was detected on D7, after treatment with C2 and LPS. This may signify a reinforcement of the newly-formed vascular network within the pulp analogue, as this molecule, PECAM-1, is a well-established organizer of the cell-cell junctions [76].

In spite of the strength and the quality of the studied tool, certain limitations do exist. For example, this model neglects the repair mechanisms of the living tissues since immune cells and inflammatory cells were not included. Secondly perfusion and innervation were also two factors that were not included in this study, which could aid the clearance of noxious stimuli. This was not possible at the time of experimentation, as it would be difficult to track all the aspects of their device at once. Furthermore, a more complex microbiome with gram positive along with gram negative bacterial populations would resemble the in vivo situation more closely. Lastly, future attempts should seek for the detection of additives, such as initiators, inhibitors and stabilizers through liquid chromatography-mass spectrometry (LC-MS) or high-performance liquid chromatography (HPLC) technique. Although these components may be minute, they are still eluted and may partly explain some alterations seen between the evaluation of solely resin monomers compared to the resin monomer - containing commercial products.

\section{Conclusions}

In conclusion, the results of the present study provide novel data on the biological responses of the tissue-engineered dentin/pulp tissue analogue on the application of major noxious stimuli, such as those derived by by-products of resinous cements and/or oral bacteria components present in deep carious lesions (endotoxin LPS). The dentin/pulp tissue analogue assembled in this paper was able to recapitulate the main components and environmental cues present in the clinical situation, with high levels of tissue organization, shedding light into the interactions of dental materials and the dentin/pulp tissue analogue. This study should help 
to improve the risk assessment of these materials, as this is a viable approach to better predict the natural tissues behavior compared to already existing in vitro methods or models. Nonetheless, further research attempt should be implemented to validate the proposed dentin/pulp tissue analogue for its relevance to the in vivo situation.

\section{Acknowledgements}

The authors would like to acknowledge the funding source, as this research work was supported by the Hellenic Foundation for Research and Innovation (HFRI) under the HFRI PhD Fellowship grant (Fellowship Number: 99344). We thank Prof. Dimitris Vlassopoulos (University of Crete and FORTH-IESL, Greece) for discussions on rheological issues and support of this research.

\section{REFERENCES}

[1] Behr M, Rosentritt M, Wimmer J, Lang R, Kolbeck C, Bürgers $\mathrm{R}$, et al. Self-adhesive resin cement versus zinc phosphate luting material: a prospective clinical trial begun 2003. Dent Mater 2009;25:601-4, http://dx.doi.org/10.1016/j.dental.2008.11.003.

[2] Ferracane JL, Stansbury JW, Burke FJT. Self-adhesive resin cements - chemistry, properties and clinical considerations. J Oral Rehabil 2011;38:295-314, http://dx.doi.org/10.1111/j.1365-2842.2010.02148.x.

[4] Susila AV, Balasubramanian V. Correlation of elution and sensitivity of cell lines to dental composites. Dent Mater 2016;32:e63-72, http://dx.doi.org/10.1016/j.dental.2015.11.011.

[5] Goldberg M. In vitro and in vivo studies on the toxicity of dental resin components: a review. Clin Oral Investig 2008;12:1-8, http://dx.doi.org/10.1007/s00784-007-0162-8.

[6] Attik N, Hallay F, Bois L, Brioude A, Grosgogeat B, Colon P. Mesoporous silica fillers and resin composition effect on dental composites cytocompatibility. Dent Mater 2017;33:166-74, http://dx.doi.org/10.1016/j.dental.2016.11.009.

[7] Moharamzadeh K, Van Noort R, Brook IM, Scutt AM. Cytotoxicity of resin monomers on human gingival fibroblasts and HaCaT keratinocytes. Dent Mater 2007;23:40-4, http://dx.doi.org/10.1016/j.dental.2005.11.039.

[8] Gallorini M, Petzel C, Bolay C, Hiller KA, Cataldi A, Buchalla W, et al. Activation of the Nrf2-regulated antioxidant cell response inhibits HEMA-induced oxidative stress and supports cell viability. Biomaterials 2015;56:114-28, http://dx.doi.org/10.1016/j.biomaterials.2015.03.047.

[9] Ginzkey C, Zinnitsch S, Steussloff G, Koehler C, Hackenberg $S$, Hagen R, et al. Assessment of HEMA and TEGDMA induced DNA damage by multiple genotoxicological endpoints in human lymphocytes. Dent Mater 2015;31:865-76, http://dx.doi.org/10.1016/j.dental.2015.04.009.

[10] Bakopoulou A, Leyhausen G, Volk J, Tsiftsoglou A, Garefis P, Koidis $P$, et al. Effects of HEMA and TEDGMA on the in vitro odontogenic differentiation potential of human pulp stem/progenitor cells derived from deciduous teeth. Dent Mater 2011;27:608-17, http://dx.doi.org/10.1016/j.dental.2011.03.002.

[11] Bakopoulou A, Leyhausen G, Volk J, Koidis P, Geurtsen W. Effects of resinous monomers on the odontogenic differentiation and mineralization potential of highly proliferative and clonogenic cultured apical papilla stem cells. Dent Mater 2012;28:327-39,

http://dx.doi.org/10.1016/j.dental.2012.01.002.

[12] Schweikl H, Petzel C, Bolay C, Hiller KA, Buchalla W, Krifka S. 2-Hydroxyethyl methacrylate-induced apoptosis through the ATM- and p53-dependent intrinsic mitochondrial pathway. Biomaterials 2014;35:2890-904, http://dx.doi.org/10.1016/j.biomaterials.2013.12.044.

[13] de Souza Costa CA, Hebling J, Randall RC. Human pulp response to resin cements used to bond inlay restorations. Dent Mater 2006;22:954-62, http://dx.doi.org/10.1016/j.dental.2005.10.007.

[14] Oguz EI, Hasanreisoglu U, Uctasli S, Özcan M, Kiyan M. Effect of various polymerization protocols on the cytotoxicity of conventional and self-adhesive resin-based luting cements. Clin Oral Investig 2019, http://dx.doi.org/10.1007/s00784-019-02980-3.

[15] D'Alpino PHP, Moura GED de D, Barbosa SC de A, Marques L de A, Eberlin MN, Nascimento FD, et al. Differential cytotoxic effects on odontoblastic cells induced by self-adhesive resin cements as a function of the activation protocol. Dent Mater 2017;33:1402-15, http://dx.doi.org/10.1016/j.dental.2017.09.011.

[16] Sahabi M, Sattari M, Romoozi E, Baghban AAZ. Cytotoxicity comparison of Harvard zinc phosphate cement versus Panavia F2 and Rely X plus resin cements on rat L929-fibroblasts. Cell J 2011;13:163-8.

[17] Kusdemir M, Gunal S, Ozer F, Imazato S, Izutani N, Ebisu S, et al. Evaluation of cytotoxic effects of six self-etching adhesives with direct and indirect contact tests. Dent Mater J 2011;30:799-805, http://dx.doi.org/10.4012/dmj.2011-046.

[18] Melo de Mendonça AA, Chaves Souza PP, Hebling J, de Souza Costa CA. Cytotoxic effects of hard-setting cements applied on the odontoblast cell line MDPC-23. Oral Surg Oral Med Oral Pathol Oral Radiol Endod 2007;104:102-8, http://dx.doi.org/10.1016/j.tripleo.2007.05.017.

[19] Tyas MJ. A method for the in vitro toxicity testing of dental restorative materials. J Dent Res 1977;56:1285-90, http://dx.doi.org/10.1177/00220345770560103401.

[20] Hanks CT, Diehl ML, Craig RG, Makinen P-K, Pashley DH. Characterization of the "in vitro pulp chamber" using the cytotoxicity of phenol. J Oral Pathol Med 1989;18:97-107, http://dx.doi.org/10.1111/j.1600-0714.1989.tb00744.x.

[21] Galler K, Hiller KA, Ettl T, Schmalz G. Selective influence of dentin thickness upon cytotoxicity of dentin contacting materials. J Endod 2005;31:396-9, http://dx.doi.org/10.1097/01.don.0000145428.26880.e5.

[22] Schmalz G, Gröppel F, Hiller KA, Galler KM. Trodimenzionalne kulture ljudskih stanica uzgojene radi testiranja citotoksičnosti stomatoloških materijala. Acta Stomatol Croat 2014;48:99-108, http://dx.doi.org/10.15644/asc48/2.99.

[23] Jiang RD, Lin H, Zheng G, Zhang XM, Du Q, Yang M. In vitro dentin barrier cytotoxicity testing of some dental restorative materials. J Dent 2017;58:28-33, http://dx.doi.org/10.1016/j.jdent.2017.01.003.

[24] ISO-ISO 7405:2018-Dentistry - evaluation of biocompatibility of medical devices used in dentistry 2018. https://www.iso.org/standard/71503.html [Accessed 12 February 2020].

[25] França CM, Tahayeri A, Rodrigues NS, Ferdosian S, Puppin Rontani RM, Sereda G, et al. The tooth on-a-chip: a microphysiologic model system mimicking the biologic interface of the tooth with biomaterials. Lab Chip 2020, http://dx.doi.org/10.1039/c9lc00915a.

[26] Hadjichristou C, Papachristou E, Bonovolias I, Bakopoulou A. Dentin/Pulp tissue analogue as advanced biocompatibility evaluation tool of dental restorative materials. Dent Mater 2019:1-20, http://dx.doi.org/10.1016/j.dental.2019.11.013. 
[27] Bakopoulou A, Papachristou E, Bousnaki M, Hadjichristou C, Kontonasaki E, Theocharidou A, et al. Human treated dentin matrices combined with $\mathrm{Zn}$-doped, Mg-based bioceramic scaffolds and human dental pulp stem cells towards targeted dentin regeneration. Dent Mater 2016;32:e159-75, http://dx.doi.org/10.1016/j.dental.2016.05.013.

[28] ISO-ISO 10993-12:2012-Biological evaluation of medical devices - Part 12: Sample preparation and reference materials 2012 https://www.iso.org/standard/53468.html [Accessed 12 February 2020].

[29] Rubinstein M, Colby R. Thermodynamics of mixing. UK Oxford: Oxfrord University Press; 2003.

[30] Bergenholtz G. Evidence for a bacterial causation of adverse pulpal responses in resin-based dental restorations. Crit Rev Oral Biol Med 2000;11:467-80, http://dx.doi.org/10.1177/10454411000110040501.

[32] Hadjichristou C, About I, Koidis P, Bakopoulou A. Advanced in vitro experimental models for tissue engineering-based reconstruction of a 3D dentin/pulp complex : a literature review. Cells Rev Rep 2020, http://dx.doi.org/10.1007/s12015-020-10069-8.

[33] Dissanayaka WL, Hargreaves KM, Jin L, Samaranayake LP, Zhang C. The interplay of dental pulp stem cells and endothelial cells in an injectable peptide hydrogel on angiogenesis and pulp regeneration in vivo. Tissue Eng A 2015;21:550-63, http://dx.doi.org/10.1089/ten.tea.2014.0154.

[34] Meretoja VV, Dahlin RL, Wright S, Kasper FK, Mikos AG. Articular chondrocyte redifferentiation in 3D co-cultures with mesenchymal stem cells. Tissue Eng C Methods 2014;20:514-23, http://dx.doi.org/10.1089/ten.tec.2013.0532.

[35] Hilkens P, Bronckaers A, Ratajczak J, Gervois P, Wolfs E, Lambrichts I. The angiogenic potential of DPSCs and SCAPs in an in vivo model of dental pulp regeneration. Stem Cells Int 2017;2017:18-22, http://dx.doi.org/10.1155/2017/2582080.

[36] Nada OA, El Backly RM. Stem Cells From the Apical Papilla (SCAP) as a tool for endogenous tissue regeneration. Front Bioeng Biotechnol 2018;6, http://dx.doi.org/10.3389/fbioe.2018.00103.

[37] Kim SG, Malek M, Sigurdsson A, Lin LM, Kahler B. Regenerative endodontics: a comprehensive review. Int Endod J 2018;51:1367-88, http://dx.doi.org/10.1111/iej.12954.

[38] Bakarich SE, Gorkin R, in het Panhuis M, Spinks GM. Three-dimensional printing fiber reinforced hydrogel composites. ACS Appl Mater Interfaces 2014;6:15998-6006, http://dx.doi.org/10.1021/am503878d.

[39] Stratesteffen H, Köpf M, Kreimendahl F, Blaeser A, Jockenhoevel S, Fischer H. GelMA-collagen blends enable drop-on-demand 3D printablility and promote angiogenesis. Biofabrication 2017;9:045002, http://dx.doi.org/10.1088/1758-5090/aa857c.

[40] Bakopoulou A, Georgopoulou A, Grivas I, Bekiari C, Prymak O, Loza K, et al. Dental pulp stem cells in chitosan/gelatin scaffolds for enhanced orofacial bone regeneration. Dent Mater 2019;35:310-27, http://dx.doi.org/10.1016/j.dental.2018.11.025.

[41] Goldberg M, Hirata A. The dental pulp: composition, properties and functions. JSM Dent 2017;5:1-10.

[42] Galler KM, Brandl FP, Kirchhof S, Widbiller M, Eidt A, Buchalla W, et al. Suitability of different natural and synthetic biomaterials for dental pulp tissue engineering. Tissue Eng A 2018;24:234-44, http://dx.doi.org/10.1089/ten.tea.2016.0555.

[43] Rao RR, Peterson AW, Ceccarelli J, Putnam AJ, Stegemann JP. Matrix composition regulates three-dimensional network formation by endothelial cells and mesenchymal stem cells in collagen/fibrin materials. Angiogenesis 2012;15:253-64, http://dx.doi.org/10.1007/s10456-012-9257-1.
[45] Engler AJ, Sen S, Sweeney HL, Discher DE. Matrix elasticity directs stem cell lineage specification. Cell 2006;126:677-89, http://dx.doi.org/10.1016/j.cell.2006.06.044.

[46] Bousnaki M, Bakopoulou A, Papadogianni D, Barkoula NM, Alpantaki K, Kritis A, et al. Fibro/chondrogenic differentiation of dental stem cells into chitosan/alginate scaffolds towards temporomandibular joint disc regeneration. J Mater Sci Mater Med 2018;29, http://dx.doi.org/10.1007/s10856-018-6109-6.

[47] Papadogiannis F, Batsali A, Klontzas ME, Karabela M, Georgopoulou A, Mantalaris A, et al. Osteogenic differentiation of bone marrow mesenchymal stem cells on chitosan/gelatin scaffolds: gene expression profile and mechanical analysis. Biomed Mater 2020;15.

[48] Buxboim A, Rajagopal K, Brown AEX, Discher DE. How deeply cells feel: methods for thin gels. J Phys Condens Matter 2010;22:194116, http://dx.doi.org/10.1088/0953-8984/22/19/194116.

[49] Georgopoulou A, Papadogiannis F, Batsali A, Marakis J, Alpantaki K, Eliopoulos AG, et al. Chitosan/gelatin scaffolds support bone regeneration. J Mater Sci Mater Med 2018;29, http://dx.doi.org/10.1007/s10856-018-6064-2.

[50] Silva EJNL, de Carvalho NK, Ronconi CT, De-Deus G, Zuolo ML, Zaia AA. Cytotoxicity profile of endodontic sealers provided by 3D cell culture experimental model. Braz Dent J 2016;27:652-6, http://dx.doi.org/10.1590/0103-6440201600792.

[51] Kurt A, Altintas SH, Kiziltas MV, Tekkeli SE, Guler EM, Kocyigit A, et al. Evaluation of residual monomer release and toxicity of self-adhesive resin cements. Dent Mater J 2018;37:40-8, http://dx.doi.org/10.4012/dmj.2016-380.

[52] Reichl FX, Durner J, Manhart J, Spahl W, Gempel K, Kehe K, et al. Biological clearance of HEMA in guinea pigs. Biomaterials 2002;23:2135-41, http://dx.doi.org/10.1016/S0142-9612(01)00344-1.

[54] Reichl FX, Durner J, Kunzelmann KH, Hickel R, Spahl W, Hume WR, et al. Biological clearance of TEGDMA in guinea pigs. Arch Toxicol 2001;75:22-7, http://dx.doi.org/10.1007/s002040000159.

[55] Schmid-Schwap M, Franz A, König F, Bristela M, Lucas T, Piehslinger E, et al. Cytotoxicity of four categories of dental cements. Dent Mater 2009;25:360-8, http://dx.doi.org/10.1016/j.dental.2008.08.002.

[56] Franz A, König F, Anglmayer M, Rausch-Fan X, Gille G, Rausch WD, et al. Cytotoxic effects of packable and nonpackable dental composites. Dent Mater 2003;19:382-92, http://dx.doi.org/10.1016/S0109-5641(02)00081-7.

[57] Sun F, Liu Y, Pan Y, Chen M, Meng X. Cytotoxicity of self-adhesive resin cements on human periodontal ligament fibroblasts. Biomed Res Int 2018;2018, http://dx.doi.org/10.1155/2018/7823467.

[58] Ulker HE, Sengun A. Cytotoxicity evaluation of self adhesive composite resin cements by dentin barrier test on 3D pulp cells. Eur J Dent 2009;03:120-6, http://dx.doi.org/10.1055/s-0039-1697418.

[59] Paschalidis T, Bakopoulou A, Papa P, Leyhausen G, Geurtsen W, Koidis P. Dental pulp stem cells' secretome enhances pulp repair processes and compensates TEGDMA-induced cytotoxicity. Dent Mater 2014;30:e405-18, http://dx.doi.org/10.1016/j.dental.2014.08.377.

[60] Watt SM, Gullo F, Van Der Garde M, Markeson D, Camicia R, Khoo CP, et al. The angiogenic properties of mesenchymal stem/stromal cells and their therapeutic potential. Br Med Bull 2013;108:25-53, http://dx.doi.org/10.1093/bmb/ldt031.

[61] Bølling AK, Samuelsen JT, Morisbak E, Ansteinsson V, Becher $\mathrm{R}, \mathrm{Dahl}$ JE, et al. Dental monomers inhibit LPS-induced cytokine release from the macrophage cell line RAW264.7. Toxicol Lett 2013;216:130-8, http://dx.doi.org/10.1016/j.toxlet.2012.11.010. 
[62] Alizadehgharib S, Östberg AK, Dahlgren U. Effects of the methacrylate/acrylate monomers HEMA, TEGDMA, DEGDA, and EMA on the immune system. Clin Exp Dent Res 2017;3:227-34, http://dx.doi.org/10.1002/cre2.93.

[63] Schmalz G, Schweikl H, Eibl M. Growth kinetics of fibroblasts on bovine dentin. J Endod 1994;20:453-6, http://dx.doi.org/10.1016/S0099-2399(06)80037-3.

[64] Schmalz G, Schuster U, Nuetzel K, Schweikl H. An in vitro pulp chamber with three-dimensional cell cultures. J Endod 1999;25:24-9, http://dx.doi.org/10.1016/S0099-2399(99)80394-X.

[65] Van Landuyt KL, Krifka S, Hiller KA, Bolay C, Waha C, Van Meerbeek B, et al. Evaluation of cell responses toward adhesives with different photoinitiating systems. Dent Mater 2015;31:916-27, http://dx.doi.org/10.1016/j.dental.2015.04.016.

[66] Schuster U, Schmalz G, Thonemann B, Mendel NMC. Cytotoxicity testing with three-dimensional cultures of transfected pulp-derived cells. J Endod 2001;27:259-65, http://dx.doi.org/10.1097/00004770-200104000-00004.

[67] Demirci M, Hiller KA, Bosl C, Galler K, Schmalz G, Schweik] $\mathrm{H}$. The induction of oxidative stress, cytotoxicity, and genotoxicity by dental adhesives. Dent Mater 2008;24:362-71, http://dx.doi.org/10.1016/j.dental.2007.06.009.

[68] Schmalz G, Hiller KA, Galler KM, Gröppel F. Three-dimensional human cell cultures for cytotoxicity testing of dental filling materials. Acta Stomatol Croat 2014;48:99-108, http://dx.doi.org/10.15644/asc48/2.99.

[69] Pashley DH. Dentin-predentin complex and its permeability: physiologic overview. J Dent Res 1985, http://dx.doi.org/10.1177/002203458506400419, 64 Spec No:613-20.

[70] da Silva JMF, Rodrigues JR, Camargo CHR, Fernandes VVB, Hiller KA, Schweikl H, et al. Effectiveness and biological compatibility of different generations of dentin adhesives. Clin Oral Investig 2014;18:607-13, http://dx.doi.org/10.1007/s00784-013-1000-9.

[71] Kim M joo, Kim K nam, Lee Y keun, Kim K mahn. Cytotoxicity test of dentin bonding agents using millipore filters as dentin substitutes in a dentin barrier test. Clin Oral Investig 2013;17:1489-96, http://dx.doi.org/10.1007/s00784-012-0840-z.

[72] Meryon S, Jakeman KJ. Aluminium and dental materials-a study in vitro of its potential release and toxicity. Int Endod J 1987;20:16-9,

http://dx.doi.org/10.1111/j.1365-2591.1987.tb00582.x.

[73] Mantellini MG, Botero T, Yaman P, Dennison JB, Hanks CT, Nör JE. Adhesive resin and the hydrophilic monomer HEMA induce VEGF expression on dental pulp cells and macrophages. Dent Mater 2006;22:434-40, http://dx.doi.org/10.1016/j.dental.2005.04.039.

[74] Koch S, Claesson-Welsh L. Signal transduction by vascular endothelial growth factor receptors. Cold Spring Harb Perspect Med 2012;2, http://dx.doi.org/10.1101/cshperspect.a006502, a006502.

[75] Bagis B, Atilla P, Cakar N, Hasanreisoglu U. Immunohistochemical evaluation of endothelial cell adhesion molecules in human dental pulp: effects of tooth preparation and adhesive application. Arch Oral Biol 2007;52:705-11, http://dx.doi.org/10.1016/j.archoralbio.2007.01.014.

[76] Privratsky JR, Newman PJ. PECAM-1: regulator of endothelial junctional integrity. Cell Tissue Res 2014;355:607-19, http://dx.doi.org/10.1007/s00441-013-1779-3. 